\author{
Wioletta Kilar \\ Zakład Przedsiębiorczości i Gospodarki Przestrzennej \\ Instytut Geografii \\ Akademia Pedagogiczna w Krakowie
}

\title{
Zagadnienia globalizacji i korporacji ponadnarodowych w edukacji przedsiębiorczości
}

Współczesnym tendencjom rozwoju społeczno-gospodarczego towarzyszy nasilający się proces koncentracji kapitału w coraz większych i sprawniej działających korporacjach ponadnarodowych (Zioło, Piróg 2002). Wpływają one w zasadniczy sposób na przebieg procesów globalizacji. „Motorem inicjującym te niezwykle złożone procesy jest nasilająca się konkurencja” (Zioło, Rachwał 2006, s. 5). W gospodarce rynkowej konkurencja dotyczy wszystkich jej elementów działających zarówno na rynku międzynarodowym, krajowym, regionalnym, jak i lokalnym. Wpływa ona na zmiany zachowań nie tylko przedsiębiorstw ponadnarodowych, ale również małych przedsiębiorstw na lokalnych rynkach oraz pojedynczych osób, w tym ucznia. Za Z. Zioło (2005, s. 15) należy przyjać, ,iż tylko konkurencyjny człowiek jest w stanie wyprodukować i zaoferować konkurencyjny produkt, natomiast konkurencyjny człowiek kształtuje się w konkurencyjnym procesie edukacyjnym". Znaczenie korporacji ponadnarodowych w gospodarce globalnej jest coraz większe, gdyż „(...) poprzez różnorodne systemy sieciowych powiązań przestrzennoprodukcyjnych organizują światową przestrzeń gospodarczą" (Zioło 2006, s. 9). Należy zauważyć, że „nasilający się proces koncentracji kapitału, który uwidacznia się między innymi w kształtowaniu się coraz potężniejszych ponadnarodowych korporacji przemysłowych, finansowych, usługowych i innych, obejmuje swym zasięgiem coraz to rozleglejsze obszary oddziaływania i wpływa w głównym stopniu na globalizację gospodarki, a równocześnie na różnicowanie światowej przestrzeni gospodarczej, społecznej i kulturowej” (Kudełko, Zioło 2005, s. 337).

W nawiązaniu do przedstawionych założeń wydaje się, że problematyka globalizacji i korporacji ponadnarodowych powinna zająć znaczące miejsce na różnych etapach systemu edukacyjnego i znaleźć odzwierciedlenie w podręcznikach do nauczania podstaw przedsiębiorczości. Niniejsze rozważania zmierzają do określenia, w jaki sposób autorzy wybranych podręczników podstaw przedsiębiorczości dla liceum, liceum profilowanego i technikum podejmują tę tematykę.

W tym celu dokonano analizy 11 podręczników podstaw przedsiębiorczości dopuszczonych do użytku szkolnego przez Ministerstwo Edukacji Narodowej, a przeznaczonych do kształcenia ogólnego w liceach, liceach profilowanych i technikach ${ }^{1}$. Szczególną uwagę zwrócono na zagadnienia odnoszące się do: globalizacji, globalizacji gospodarki światowej, rynku globalnego, produktu globalnego, a także korporacji ponadnarodowych. Wielu autorów umieściło w podręcznikach powyższe pojęcia, zdając sobie sprawę z tego, że w globalizującym się świecie znaczenie korporacji ponadnarodowych w gospodarce światowej jest bardzo duże, a w następnym dziesięcioleciu, czyli w okresie, kiedy obecny licealista może stać się jedną z osób uczestniczących w działaniu korporacji ponadnarodowych, prawdopodobnie będzie jeszcze większe.

\footnotetext{
${ }^{1}$ Wykaz analizowanych podręczników zamieszczono na końcu pracy.
} 
Analizując zagadnienia globalizacji, poszczególni autorzy przedstawiają różne definicje tego pojęcia oraz cechy tego procesu. M. Pietraszewski (2002), zachęcając młodych ludzi do nauki i podnoszenia kwalifikacji, stara się im uświadomić, że w XXI w. procesy globalizacji i ujednolicania rynków pracy mogą spowodować, że jedynie osoby dobrze wykształcone będą w stanie obsługiwać coraz bardziej zautomatyzowane i skomplikowane maszyny i urządzenia. Pracownicy będą nie tyle pracować, co świadczyć usługi potrzebne gospodarce. Ponadto autor wskazuje czynniki, pod których wpływem proces globalizacji będzie się nadal kształtował. Są to: postęp naukowo-techniczny, międzynarodowa konkurencja i polityka ekonomiczna państw. Jak przyjmuje M. Pietraszewski (2002, s. 7 i 8), będą one wpływały i kształtowały także pokolenie wzrastające w dobie kolejnej fazy rewolucji naukowo-technicznej, czyli w rozpoczętym już XXI w. Autor definiuje pojęcie globalizacji jako „znaczące i złożone procesy, które zachodzą w skali ogólnoświatowej w różnych sferach: ekonomicznej, technicznej, socjologicznej i kulturowej”. Wyjaśnia, że podstawowymi cechami globalizacji w sferze ekonomicznej są:

- integrowanie w skali międzynarodowej działalności gospodarczej podmiotów na różnych poziomach: państwowym, rynkowym, dziedzin działalności oraz przedsiębiorstw powiązanych ze sobą handlowo, inwestycyjno-produkcyjnie i korporacyjnie;

- międzynarodowa współzależność między podmiotami gospodarki na różnych poziomach;

- związek z postępem naukowym, technicznym i organizacyjnym, powodujący unowocześnianie gospodarek państw ,„poprzez rozwój gałęzi produkcji będących nośnikami postępu technicznego, zastosowanie nowoczesnych procesów produkcji w całej gospodarce, rozwój edukacji narodowej i wzrost liczby wysoko wykwalifikowanych pracowników”;

- „skracanie czasu i przestrzeni”, które przejawia się m.in. możliwościami korzystania z oferty produktów i uczestnictwa wszystkich ludzi w wydarzeniach na całym świecie.

Podobna definicja globalizacji przyjmowana jest w podręczniku B. Stańdy i B. Wierzbowskiej (2002, s. 140), w którym procesom globalizacji poświęcono oddzielny rozdział. Autorki przyjmują następującą definicję globalizacji: „,...) bardzo szeroki i złożony proces, mający wpływ na wszystkie sfery naszego życia: ekonomiczna, społeczna, polityczną i kulturową w skali ogólnoświatowej”. Ponadto wymieniają, podobne jak M. Pietraszewski, czynniki, które w największym stopniu wpływają na proces globalizacji. Wskazują wśród krajów uczestniczących w globalizacji na grupę triady, która jest potęgą gospodarczą świata.

Na pojęcie globalizacji zwrócił także uwagę zespół autorski: W. J. Jakubowski, T. Maj, P. Załęski (2003, s. 225), którzy definiują pojęcie globalizacji jako proces ,integracji społecznej i gospodarczej świata", a także przedstawiają wiele przejawów globalizacji, w tym m.in. szybki wzrost wymiany handlowej, dzięki której następuje szybki dostęp do produktów zaawansowanej technologii. Z. Makieła i T. Rachwał (2005, s. 176 i 177) pojęcie globalizacji przedstawiaja jako proces „integracji społecznej i gospodarczej świata”. Wyjaśniają, że przejawami procesu globalizacji są m.in.: swobodny przepływ informacji, liberalizacja w handlu międzynarodowym, swobodny przepływ kapitału oraz swobodne przemieszczanie się osób.

Procesy globalizacji zostały omówione również przez M. Biernacka, J. Korbę i Z. Smutka (2006). Przyjęli oni, że globalizacja jest utożsamiana z działalnością międzynarodowych instytucji finansowych, a proces ten przyczynia się do szybszego rozwoju ekonomicznego wielu państw i warunków życia ich mieszkańców.

W podręczniku pod redakcją M. Belki (2005) przyjęto, że globalizacja jest związana z traktowaniem rynku światowego jak rynku działania przedsiębiorstwa, przez co następuje zanikanie granic państwowych w odniesieniu do przepływów produktów, usług, kapitałów, ludzi, informacji i idei. Autorzy tego podręcznika podkreślaja, że na globalizację składa się ,zbiór zjawisk, procesów 
i tendencji zachodzących obecnie w skali ogólnoświatowej w rozmaitych sferach: ekonomicznej, politycznej, prawnej, kulturowej, społecznej i technicznej”, lecz największy postęp tego procesu dokonał się w sferze ekonomicznej, przyczyniając się do tworzenia gospodarki globalnej (Belka 2005, s. 188). Ponadto wyróżniono wiele przejawów globalizacji, takich jak: technologia, gospodarka, polityka, kultura, środowisko naturalne, dlatego stanowi ona wielkie wyzwanie w dziedzinie konkurencji dla gospodarek i społeczeństw. W pozostałych podręcznikach przyjętych do analizy nie podjęto próby definiowania globalizacji.

W zróżnicowany sposób przedstawiane są również zagadnienia dotyczące globalizacji gospodarki światowej. M. Pietraszewski (2002) zwraca uwagą, że postęp globalizacji znacząco wpływa na gospodarki państw, które tworzą gospodarkę globalną. Wyjaśnia, że gospodarka światowa opiera się na możliwości swobodnego przepływu produktów oraz czynników produkcji pomiędzy wszystkimi państwami, a globalizacja działalności gospodarczej to nic innego, jak „dokonujący się na świecie długofalowy proces łączenia coraz większej liczby gospodarek państwowych ponad granicami i rozszerzania wzajemnych powiązań w celu tworzenia ogólnoświatowego systemu ekonomicznego" (s. 8-10).

A. Mikinia i M. Sienna (2002, s. 65) w rozdziale dotyczącym wymiany międzynarodowej wyjaśniają pojęcie globalizacji gospodarki następująco: ,jest to proces powstawania i rozwoju rynków światowych oparty na swobodnym przepływie dóbr, usług, kapitału i pracy". Ponadto autorki przedstawiają główne czynniki, które wpływają na nasilanie się procesu globalizacji gospodarki. Przyjmują przy tym, że globalizacja jest zjawiskiem, którego nie da się uniknąć, procesem, którego nie da się zatrzymać, gdyż „wszyscy stajemy się częścią społeczeństwa globalnego" (s. 70). L. Piasecka (2002, s. 108) wyjaśnia, że ,globalizacja gospodarki oznacza tworzenie takiego systemu regulacji prawnych i administracyjnych, aby możliwy był swobodny przepływ dóbr, usług oraz kapitału i pracy bez względu na granice państw”.

Na pojęcie globalizacji gospodarki światowej zwrócił także uwagę zespół autorski: W. J. Jakubowski, T. Maj, P. Załęski (2003). Podając kilka wybranych przykładów, autorzy pokazują przejawy globalizacji gospodarki światowej w kraju i życiu codziennym ucznia. Przedstawiając omawianą definicję M. Biernacka, J. Korba i Z. Smutek (2006, s. 205) duże znaczenie przypisują wymianie gospodarczej, przyjmując, że: ,globalizacja gospodarki światowej polega na wzroście międzynarodowej wymiany gospodarczej i umiędzynarodowieniu produkcji, ale też prowadzi do wzrostu współzależności między państwami”. Na rolę globalizacji gospodarki światowej zwrócili także uwagę Z. Makieła i T. Rachwał (2005), wyjaśniając, że proces globalizacji gospodarki światowej jest częścią procesu globalizacji świata.

W dwóch kolejnych podręcznikach: autorstwa B. Stańdy i B. Wierzbowskiej (2002) oraz pod redakcją M. Belki (2005) nie zaprezentowano definicji globalizacji gospodarki światowej, lecz nawiązano do tego procesu w podrozdziałach dotyczących globalizacji.

W podręcznikach autorstwa B. Barańskiej., J. Gierczyckiej, D. Szostka (2002), S. Gregorczyka, M. Romanowskiej, A. Sopińskiej, P. Wachowiaka (2002) oraz M. Nasiłowskiego(2002) nie poruszono zagadnień związanych z globalizacją gospodarki światowej.

Kolejne pojęcie, które poddane zostało analizie, to rynek globalny. Jego definicja pojawia się u niewielu autorów.

B. Barańska, J. Gierczycka i D. Szostek (2002, s. 9) zwracają uwagę, że „musimy nauczyć się funkcjonować na rynku globalnym”. W klasyfikacjach rynku według różnych kryteriów zaznaczają istnienie rynku światowego, ,na którym transakcje zawierają przedstawiciele różnych krajów" (s. 65). Jak się wydaje, należałoby jednak wyraźnie zaznaczyć, że transakcje te zawierają przedstawiciele różnego typu korporacji ponadnarodowych i przedsiębiorstw krajowych, a rządy poszczególnych krajów stwarzająjedynie uwarunkowania regulujące rozwój firm i ich powiązań 
rynkowych. B. Stańda i B. Wierzbowska (2002), podobnie jak zespół autorski: B. Barańska, J. Gierczycka, D. Szostek (2002), w rozdziale dotyczącym klasyfikacji rynków ze względu na przestrzeń, wyróżniają jako jeden z jego typów rynek światowy, nie odnosząc się do procesów, które obecnie zachodzą w gospodarce światowej. W. J. Jakubowski, T. Maj, P. Załęski (2003), M. Nasiłowski (2002) oraz A. Mikinia i M. Sienna (2002), podobnie jak autorzy dwóch wcześniej analizowanych podręczników, pojęcie rynku globalnego zaznaczyli jedynie przy klasyfikacji rynku według terytorium (przestrzeni).

W podręczniku pod redakcją M. Belki (2005) autorzy uświadamiają uczniowi, że dziś dla wielu towarów i usług nie istnieje już pojęcie rynku lokalnego czy krajowego, konkurencja toczy się bowiem na rynku globalnym. Ponieważ podmioty gospodarcze funkcjonują nawet na odległych rynkach, produkty przez nie oferowane są dostępne powszechnie na świecie, czyli, jak wskazuja autorzy, stają się produktami globalnymi. Potwierdza tę tezę L. Piasecka (2002, s. 109), zaznaczając, że ,obecnie wolny przepływ informacji nie stanowi już żadnej bariery; można powiedzieć, że świat się skurczył, z zatem rozszerzyły się dla wielu firm perspektywy rozwoju". W podręcznikach pozostałych zespołów autorskich, czyli S. Gregorczyka, M. Romanowskiej, A. Sopińskiej, P. Wachowiaka (2002), Z. Makieły i T. Rachwała (2005) oraz M. Biernackiej, J. Korby i Z. Smutka (2006) problematyka rynku globalnego nie została podjęta.

Funkcjonowanie gospodarki rynkowej i nasilające się procesy globalizacji powodują potrzebę zdefiniowania pojęcia ,produkt globalny”. Pojęcie produktu globalnego pojawiło się jedynie w dwóch podręcznikach; autorzy pozostałych je pominęli. L. Piasecka (2002), podobnie jak autorzy podręcznika pod redakcją M. Belki (2005), przedstawia przykłady produktów globalnych, takich jak coca-cola czy cheesburger firmy McDonald's, wyjaśniając, że te produkty dzięki globalizacji gospodarki światowej stały się dostępne na rynku globalnym. L. Piasecka (2002) stwierdza m.in., że działania korporacji ponadnarodowych zmierzają do tego, by ludzie na całym świecie używali tych samych lub podobnych produktów.

Problematyka korporacji ponadnarodowych jest podejmowana w większości analizowanych podręczników, najczęściej w połączeniu z procesami globalizacji gospodarki światowej. Najszerzej została omówiona przez M. Nasiłowskiego (2002, s. 32), który wyjaśnia, że korporacje to „wielkie spółki, zarządzane przez zespoły naukowców, inżynierów, organizatorów sprzedaży, reklamy i marketingu, pracowników, koordynatorów i dyrektorów różnych pionów, którzy tworzą technostrukturę korporacji, czyli mózg kierujący spółką, reprezentujący jej bieżące i długofalowe interesy". Autor twierdzi, że siła korporacji wyraża się tym, że wywierają one decydujący wpływ na cały system gospodarczy krajów, w których się znajdują, oraz określają rozmiary produkcji i wysokość cen, a także w dużym stopniu poprzez system reklamy, kształtują upodobania konsumentów. M. Nasiłowski szczegółowo analizuje proces powstawania i budowy korporacji, a także zagadnienie ich opodatkowania. Podkreśla, że korporacje transnarodowe są najpotężniejszymi przedsiębiorstwami we współczesnym świecie, dysponującymi ogromnym zasobem i bardzo mobilnym kapitałem. W analizowanym podręczniku wyjaśnienie pojęcia korporacji ponadnarodowej rozpoczyna osobny rozdział, dotyczący korporacji wielonarodowych. W rozdziale tym autor przybliża znaczenie korporacji transnarodowych w gospodarce świata, ich działanie na poszczególnych kontynentach oraz funkcjonowanie w gospodarce polskiej. Ponadto podkreśla, że ,w epoce rosnącej globalizacji i łatwości przenoszenia kapitału z kraju do kraju korporacje ponadnarodowe nabierają coraz większego znaczenia" (s. 33).

W sposób zbliżony problematyka korporacji transnarodowych została podjęta w podręczniku autorstwa Z. Makieły i T. Rachwała (2005). Ten zespół autorski, jedyny spośród wszystkich zespołów autorskich analizowanych podręczników, dokonuje klasyfikacji korporacji w schemacie charakteryzującym związki spółek. Autorzy przyjmują, że korporacje to „,wielkie organizacje 
ekonomiczne, często o zasięgu międzynarodowym" (s. 95). Ponadto, podobnie jak M. Nasiłowski, przyjmuja, że ,stanowią one prawne połączenie wielu spółek, zarządzane są przez wybitnych fachowców wspomaganych przez zespoły naukowców, inżynierów organizatorów sprzedaży oraz, że często korporacje wywierają decydujący wpływ na gospodarkę krajów, a nawet politykę rządów" (s. 95). W końcowym rozdziale, dotyczącym procesów globalizacji, autorzy wskazują na wielkie korporacje transnarodowe jako na najważniejszych „sprawców” globalizacji, gdyż konkurują one skutecznie z państwami i największymi organizacjami międzynarodowymi, organizując gospodarkę światową. Dlatego należy stwarzać w państwach warunki zachęcające do inwestowania przez korporacje transnarodowe, ponieważ są one jednym z najpoważniejszych czynników przyspieszających rozwój gospodarczy krajów.

B. Stańda i B. Wierzbowska (2002) korporacje transnarodowe określają jako jeden z podmiotów uczestniczących w procesie globalizacji. Ponadto wyjaśniają, że działalność korporacji ponadnarodowych ,,polega na rozszerzeniu i pogłębianiu działań przedsiębiorstw, zmierzających do wytwarzania i sprzedawania produktów oraz standardowych usług na skalę ogólnoświatową” (s. 142). Zespół autorski B. Barańska, J. Gierczycka i D. Szostek (2002, s. 128) zaznacza fakt istnienia korporacji w gospodarce międzynarodowej poprzez przyjęcie definicji korporacji (,duża spółka akcyjna”) oraz stwierdzenie: ,jeżeli korporacja działa w kilku krajach, nazywa się ją wtedy korporacją międzynarodową". Charakteryzując gospodarkę rynkową autorzy podkreślają, że dominująca rolę korporacje ponadnarodowe pełnią w kapitalistycznej gospodarce rynkowej, realizowanej np. w Stanach Zjednoczonych.

M. Pietraszewski (2002) porusza problematykę korporacji transnarodowych, nawiązując do procesów globalizacji gospodarki. Autor zaznacza, że globalizacja przejawia się m.in. rozwojem międzynarodowych przedsiębiorstw i instytucji oraz prowadzi w konsekwencji do upowszechniania wspólnego modelu gospodarczego. W rozdziale „Gospodarowanie na rynku zintegrowanym" M. Pietraszewski (2002, s. 242) przypisuje korporacjom podstawowe znaczenie w wymianie międzynarodowej, która dokonuje się poprzez zakłady należące do korporacji i ich kooperantów w wielu państwach świata. Ogromne znaczenie korporacji w gospodarce światowej w ostatnich latach zauważają M. Biernacka, J. Korba i Z. Smutek (2006). Autorzy szacują, że liczba ponadnarodowych korporacji na świecie wynosi około 60 tys., z 500 tys. filii, a zatrudniają one ponad 6 mln pracowników. Podkreślają również fakt, że we współczesnej gospodarce rośnie ilość fuzji i megafuzji, czyli łączenia się największych korporacji oraz przejęć mniejszych korporacji przez większe, co stwarza poważne zagrożenie dla konkurencyjności gospodarki światowej. M. Biernacka, J. Korba i Z. Smutek podkreślają wzrost znaczenia korporacji w gospodarce światowej, przywołując to, że podczas corocznego Światowego Forum Gospodarczego spotykają się politycy reprezentujący gospodarki największych państw świata oraz szefowie największych korporacji ponadnarodowych, czyli osoby, które mają największy wpływ na kształtowanie się światowej gospodarki.

W. J. Jakubowski, T. Maj i P. Załęski (2003) w rozdziale dotyczącym gospodarki światowej podkreślają, że korporacje międzynarodowe, dysponujące tak dużym potencjałem ekonomicznym, są niezależne finansowo, technologicznie i organizacyjnie. Działając w wielu krajach, mogą prowadzić własną politykę gospodarczą. Korporacje ponadnarodowe, takie jak Mitsubishi czy Microsoft, skutecznie konkurują na świecie z oficjalnymi organizacjami i instytucjami, nawet takimi, jak Bank Światowy. Dlatego kraje, którym zależy na dynamicznym rozwoju gospodarczym, zabiegają o to, by korporacje inwestowały właśnie u nich. Ponadto autorzy dodają, że „najbardziej znaczącym przejawem globalizacji jest swobodny przepływ kapitału i inwestycji, co najbardziej jest widoczne w działalności ponadnarodowych korporacji gospodarczych" (s. 226). 
Zespół autorski: S. Gregorczyk, M. Romanowska, A. Sopińska, P. Wachowiak (2002) nie podejmuje zagadnień związanych z procesami globalizacji, natomiast problematykę korporacji ponadnarodowych porusza kilkakrotnie. Autorzy, przedstawiając formy organizacyjno-prawne przedsiębiorstw, zaznaczają, że korporacje ponadnarodowe nie mogą funkcjonować jako przedsiębiorstwa indywidualne czy spółki cywilne, lecz jako spółki kapitałowe. Ponadto, w rozdziale dotyczącym otoczenia ekonomicznego przedsiębiorstw zostają przedstawione motywy, jakimi kierują się przedsiębiorstwa ponadnarodowe w wyborze regionu do inwestycji. Wyróżniają dwie zasadnicze grupy motywów: ogólne i szczegółowe, które decydują o wyborze konkretnego państwa.

L. Piasecka (2002) nie wyjaśnia, co rozumie pod pojęciem korporacji ponadnarodowej. W modelu gospodarczym państw świata jako jeden z podstawowych jego elementów wyróżnia rozrost ponadnarodowych korporacji. Zagadnienie korporacji ponadnarodowych nie zostało poruszone w podręczniku pod redakcją M. Belki (2005), a w podręczniku autorstwa A. Mikinii i M. Siennej (2002) zostało jedynie zaznaczone, że rozwój korporacji ponadnarodowych jest jednym z czynników wpływających na globalizację gospodarki światowej.

W świetle przedstawionej analizy należy stwierdzić, że większość autorów podręczników podstaw przedsiębiorczości podejmuje problematykę globalizacji i korporacji ponadnarodowych. Zagadnienia dotyczące korporacji najczęściej powiązane są z tematyką globalizacji gospodarki światowej, co jest oczywiste, gdyż korporacje transnarodowe są głównymi „sprawcami” procesów globalizacji. Problematyka korporacji ponadnarodowych oraz procesy globalizacji gospodarki światowej są przedstawiane z różną szczegółowością w poszczególnych podręcznikach, a przez niektórych są traktowane marginesowo. Żaden z autorów nie wyjaśnia pojęcia produktu globalnego, co - jeśli pomija się również problematykę budowy korporacji ponadnarodowych utrudnia uczniowi zrozumienie mechanizmów występujących we współczesnej gospodarce krajowej i światowej. Analizowane zagadnienia najczęściej znajdują się w ostatnich rozdziałach podręczników, co uczeń może potraktować jako podsumowanie tego, czego nauczył się podczas lekcji podstaw przedsiębiorczości, a także wskazówkę, jakie procesy, obecnie i w najbliższej przyszłości, będą odgrywały istotną rolę w gospodarce światowej. Znajomość tych procesów stawia go w pozycji konkurencyjnej w stosunku do innych osób, które nie zdają sobie sprawy ze znaczenia globalizacji gospodarki światowej. Daje to możliwość podejmowania świadomych decyzji i odnalezienia się w rozwijającym się świecie.

W podstawie programowej podstaw przedsiębiorczości dla liceów, liceów profilowanych i techników brak jest zagadnień dotyczących funkcjonowania korporacji ponadnarodowych. Wydaje się, że ta tematyka powinna się znaleźć w podstawie programowej, ze względu na pierwszy punkt w celach edukacyjnych tego przedmiotu, czyli „Przygotowanie do aktywnego i świadomego uczestnictwa w życiu gospodarczym”, który dotychczas nie mógł być w pełni realizowany. Zatem generalnie wydaje się, że analizowana problematyka powinna być szerzej realizowana zarówno w treściach kształcenia w szkole ponadgimnazjalnej, jak i w podręcznikach podstaw przedsiębiorczości.

\section{Literatura}

1. Gierańczyk W., Stańczyk A., 2003, Korporacje międzynarodowe w przestrzeni globalnej [w:] Ksztattowanie się struktur przemystowych, Z. Zioło, Z. Makieła (red.), Prace Komisji Geografii Przemysłu PTG, 5/2003, Warszawa-Kraków 
2. Kudełko J., Zioło Z., 2005, Przemiany potencjału gospodarczego przestrzeni światowej w latach 1990-2003 [w:] Procesy i kierunki przemian w gospodarce, przestrzeni i spoteczeństwie - Ksiega Jubileuszowa dedykowana prof. dr hab. Z. Mikolajewiczowi w siedemdziesiata rocznice Urodzin, M. Bogucka, J. Słodczyk (red.), Uniwersytet Opolski, Opole

3. Podstawa programowa kształcenia ogólnego dla liceum ogólnoksztatcacego, liceum profilowanego i technikum [w:] Rozporzqdzenie Ministra Edukacji Narodowej i Sportu z dnia 26.02.2002 r. w sprawie podstawy programowej wychowania przedszkolnego oraz kształcenia ogólnego w poszczególnych typach szkót, Dz.U. Nr 51, poz. 458

4. Sala S., 2005, Rozwój korporacji transnarodowych w gospodarce światowej [w:] Przedsiębiorczość a wyzwania cywilizacyjne, Z. Zioło, T. Rachwał (red.), seria: Przedsiębiorczość - Edukacja $n r$ 1, Zakład Przedsiębiorczości i Gospodarki Przestrzennej Instytutu Geografii Akademii Pedagogicznej Krakowie, Wydawnictwo „MiWa”, Kraków

5. Zioło Z. 2005, Światowe uwarunkowania rozwoju przedsiębiorczości [w:] Przedsiębiorczość a wyzwania cywilizacyjne, Z. Zioło, T. Rachwał (red.), seria: Przedsiębiorczość - Edukacja nr 1, Zakład Przedsiębiorczości i Gospodarki Przestrzennej Instytutu Geografii Akademii Pedagogicznej Krakowie, Wydawnictwo „MiWa”, Kraków

6. Zioło Z., 2006, Zróżnicowanie światowej przestrzeni przemysłowej w świetle koncentracji siedzib zarzqdów wiodacych korporacji [w:] Międzynarodowe uwarunkowania rozwoju przemystu, Z. Zioło, T. Rachwał (red.), Prace Komisji Geografii Przemysłu PTG nr 8, Warszawa-Kraków

7. Zioło Z., Piróg S., 2002, Lokalizacja zarzadów i potencjał ekonomiczny wiodacych firm zachodnioeuropejskich [w:] Problemy transformacji struktur przemysłowych, Z. Zioło (red), Prace Komisji Geografii Przemysłu PTG nr 4, Warszawa-Kraków-Rzeszów

8. Zioło Z., Rachwał T., 2006, Wprowadzenie [w:] Międzynarodowe uwarunkowania rozwoju przemystu, Z. Zioło, T. Rachwał (red.), Prace Komisji Geografii Przemysłu PTG nr 8, Warszawa-Kraków

\section{Wykaz podręczników do przedmiotu podstawy przedsiębiorczości dla liceum ogólnokształcącego, liceum profilowanego i technikum, przyjętych do badań}

1. Barańska B., Gerczycka J., Szostek D., 2002, Przedsiębiorczość. Podręcznik dla liceów ogólnoksztatcacych, liceów profilowanych i techników, Videograf Edukacja, Chorzów

2. Belka M. (red.), 2005, Ekonomia stosowana. Podręcznik do podstaw przedsiębiorczości dla liceów ogólnoksztatcacych, liceów profilowanych i techników (wydanie II uaktualnione), Fundacja Młodzieżowej Przedsiębiorczości, Warszawa

3. Biernacka M., Korba J., Smutek Z., 2006, Podstawy przedsiębiorczości. Podręcznik dla liceum ogólnokształcacego, liceum profilowanego i technikum (wydanie II zmienione), Wydawnictwo Pedagogiczne Operon, Gdynia

4. Gregorczyk S., Romanowska M., Sopińska A., Wachowiak P., 2002, Przedsiębiorczość bez tajemnic. Podręcznik dla liceum ogólnokształcqcego, liceum profilowanego i technikum, WSiP, Warszawa

5. Jakubowski W. J., Maj T., Załęski P., 2003, Podstawy przedsiębiorczości. Podręcznik do liceów i techników, Oficyna Wydawnicza Krzysztof Pazdro, Warszawa

6. Makieła Z., Rachwał T., 2005, Podstawy przedsiębiorczości. Podręcznik dla liceum ogólnoksztatcacego, liceum profilowanego i technikum, wydanie czwarte, Nowa Era, Warszawa

7. Mikina A., Sienna M., 2002, Przedsiębiorczosśc - klucz do sukcesu. Podstawy przedsiębiorczości dla liceum ogólnokształcacego, liceum profilowanego i technikum, Wydawnictwo Rea, Warszawa

8. Nasiłowski M., 2002, Podstawy przedsiębiorczości. Podręcznik dla szkót ponadgimnazjalnych, Wydawnictwo Key Text, Warszawa

9. Piasecka L., 2002, Podstawy przedsiębiorczości 1. Podręcznik dla liceum ogólnokształcacego, liceum profilowanego i technikum, Wydawnictwa Edukacyjne Wiking, Wrocław

10. Pietraszewski M., 2002, Szansa dla przedsiębiorczych. Podręcznik podstaw przedsiębiorczości dla liceów i techników do aktywnego uczenia się, Oficyna Ekonomiczna Wydawnictwa eMPi², Poznań

11. Stańda B., Wierzbowska B., 2002, Przedsiębiorczość (podręcznik dla szkół ponadgimnazjalnych), Wydawnictwo Szkolne PWN, Warszawa 


\section{Issues of Globalization and International Corporations in the Teaching Entrepreneurship}

The aim of the article is to define how the issue of entrepreneurship is tackled by authors of textbooks for high, vocational and technical schools.

According to presented study, it is possible to observe that the majority of authors of the textbooks on the basics of entrepreneurship raise the issues of globalization and international corporations. Usually the issue of corporations is related to the issue of globalization in the world's economy - with more or less details in different textbooks. The above mentioned issues can usually be found in the last chapters, which a student can treat as a guideline for what processes will take place in the world's economy in the future. The awareness of these processes is crucial to students' education and puts them in competitive position with relation to others who do not realize the full meaning of globalization in the world's economy. It also allows for making rational decisions and finding one's place in the developing world. 